\title{
Small price incentives increase women's access to land titles in Tanzania
}

\author{
Daniel Ayalew Ali, ${ }^{*}$ Matthew Collin, ${ }^{\dagger}$ Klaus Deininger, ${ }^{*}$ \\ Stefan Dercon, ${ }^{\ddagger}$ Justin Sandefur,${ }^{\S}$ Andrew Zeitlin $₫$
}

June $1,2016^{\|}$

\begin{abstract}
We present results from a field experiment using price incentives to address two obstacles to women's access to formal land ownership. First, the price of formal land titles is often prohibitive, restricting access for both men and women. Second, when formal titles are issued, men are recorded as the sole owners of household land in the vast majority of cases. In theory, these problems may be in tension: requirements to grant women equal ownership may reduce the overall household demand for titling. In practice, we find no such trade-off: when residents of low-income, unplanned settlements in Dar es Salaam are were offered price discounts for formal land titles, demand rose significantly. Price elasticity of demand was unchanged when price discounts were conditional on registering a woman as (co-)owner of household land. Furthermore, conditional price discounts achieved near gender parity in land ownership.
\end{abstract}

JEL classification: H42, J16, K11, O18, Q15

Keywords: land titling, formalization, gender, field experiment, Tanzania, intrahousehold

\footnotetext{
*World Bank

${ }^{\dagger}$ Corresponding author: mcollin@cgdev.org. Address: Center for Global Development Europe, 54 Wilton Road, London SW1V 1DE

${ }^{\ddagger}$ University of Oxford

$\S$ Center for Global Development

"Georgetown University

"We gratefully acknowledge funding from the International Growth Centre, RA-2011-08-020, the World Bank's Knowledge for Change Program, UN Habitat's Global Land Tool Network, and the World Bank's Gender Action Plan Trust Fund. The project would not have been possible without the collaboration of the Women's Advancement Trust in Dar es Salaam, officials from the Directorate of Unplanned Settlements in the Tanzanian Ministry of Lands and staff at the Kinondoni Municipality, Dar es Salaam City Council and the World Bank mission in Tanzania. Ignatus Jacob and Pavel Luengas provided excellent research assistance. Marcel Fafchamps, Willa Friedman, Imran Rasul, Joachim De Weerdt, and numerous seminar participants provided valuable comments. All errors and views are the authors' alone.
} 


\section{Introduction}

Land tenure formalization is a potentially important catalyst for economic development in general, and for women's empowerment in particular. Macroeconomists and economic historians tie the emergence of strong property rights to long run growth (North and Weingast 1989; Acemoglu and Robinson 2001; Besley and Ghatak 2010), while microeconomists have documented significant welfare benefits of land-titling in developing countries across a diverse array of outcomes, including savings and investment, female labor supply, and fertility choices (Field 2003; Di Tella, Galiani, and Schargrodsky 2007; Galiani and Schargrodsky 2010). The counterfactual to tenure formalization is often a customary land tenure regime that is heavily biased against women (Goldstein and Udry 2008; Doss, Kovarik, Peterman, Quisumbing, and van de Bold 2013).

Two obstacles prevent women from realizing these gains. The first is the limited reach of existing land titling initiatives. During the 1990s and 2000s, nearly two dozen African countries enacted de jure land reforms extending the scope of formal land titling to millions of poor households, and often legally enshrining gender equality (Alden Wily 2003). But implementation of these reforms has been extremely limited (Deininger, Ali, Holden, and Zevenbergen 2008). In Tanzania, more than a decade after a major 1999 land reform created a legal pathway for both men and women to access formal tenure rights, these formal titles only exist in a handful of pilot projects, and new aid packages are being designed to resuscitate their implementation (USAID 2011; World Bank 2013).

Any policy effort to expand women's land ownership through formal titling must overcome the limited reach of these reforms in general, which we term the extensive margin of women's access to title. A central hypothesis here is that the prohibitive cost of land surveying faced by households - rather than other political or cultural barriers to tenure formalization - explains the low take-up of formal titles in urban Tanzania.

Second, where land formalization programs are successfully implemented, they may disempower women by formalizing the unequal status quo if only men are registered as formal property owners. Female inclusion rates have been disappointingly low in early titling programs in the region (Deere and León 2001; Payne, Durand-Lasserve, and Rakodi 2007). We describe the task of raising these rates as the intensive margin of women's access to title.

This paper presents results from a field experiment designed to test how price incentives for land titling may address both of these problems, first by operating on the extensive margin of female access to title by making titles more affordable to poor households in general and second by operating on the intensive margin by explicitly conditioning price offers on the inclusion of a woman on the title (we refer to this as co-titling in this paper). These objectives may be in tension, as policies to encourage female land 
ownership may discourage property registration overall. This problem and our approach bears some similarity to the design of cash transfer programs (Baird, McIntosh, and Özler 2011), where conditionality appears to have an important role in achieving the program's narrow goals (i.e., school enrollment), at the cost of reducing the set of beneficiaries for secondary outcomes (e.g., reduced teen pregnancy).

The experiment was initially conducted in 2010 in the unplanned settlements of Dar es Salaam, a context in which formal land titles (known as certificates of right of occupancy $(\mathrm{CROs}))$ are theoretically available to all residents but are extremely rarely acquired in practice, and also in which self-reported female ownership of land is quite low. ${ }^{1}$ All households owning land in the treatment area had the opportunity to buy a formal land title at a base price of approximately USD $\$ 64 .{ }^{2}$ Households were then randomly assigned two vouchers that could be redeemed for a discount on this base price. The first voucher was a general, unrestricted price discount. The second voucher provided an additional discount conditional on the household including a woman as owner on the title application.

The striking finding of this experiment is that, in spite of the rarity of female titling outside of the project, price incentives are highly effective at motivating households to give women access to formal co-ownership of household land.

Households receiving conditional subsidies were just as likely to purchase titles as those receiving unconditional subsidies, indicating that conditionality does not depress demand. Among households which purchased a land title, receiving a conditional subsidy substantially and significantly increases the probability that a woman's name is included on the title. In sum, offering conditional discounts will increase, in aggregate, the number of women listed as landowners. Conditioning price offers on female inclusion expands female access on the intensive margin, with no trade-off on the extensive margin.

An important outstanding question regarding these findings is whether they are subject to a version of the Lucas critique (1976). While a large literature has established the (putatively causal) relationship between female land ownership and various positive welfare outcomes, it remains to be seen whether manipulating land ownership institutions will produce similar effects in the long term. A definitive answer to this question is some years off in this project. In the meantime, we show that women who exhibit signs of stronger intra-household bargaining power at baseline are significantly more likely to choose co-titling in our experiment, suggesting that households take co-titling seriously as a tool for female empowerment.

\footnotetext{
${ }^{1}$ Only $13 \%$ of dual-headed households in our sample report a woman as being an owner of their land, with less than $50 \%$ reporting that a woman must be consulted in the event of sale, transfer or rental.

${ }^{2}$ For reference, the median household income in the sample was approximately USD $\$ 200 /$ month. Throughout the paper we use an exchange rate of 1,565 Tanzanian shillings per U.S. dollar. This was the prevailing rate as of January 1st, 2012, approximately mid-way through the window in which households purchased titles.
} 
To our knowledge, this is the first study to introduce randomized variation in financial barriers to women's access to property. It shows that not only are these interventions relatively easy to design and implement, but that they can have substantial effects on women's legal claims to ownership. The main policy lesson of our results is that the goal of maximizing female land ownership is achieved by a price menu (including incentives to co-title women as well as pro-poor price discrimination), which is radically different from policies currently in place in Tanzania and most other developing countries.

The rest of the paper is structured as follows: in Section 2, we discuss the motivation for such an experiment by drawing on existing evidence for gender and bargaining power impacts of property rights and land titling interventions. This section also covers the Tanzanian context, where recently-introduced land tenure reforms have created an opportunity for the intrahousehold status quo to change. In Section 3, we discuss the experiment in more detail, specifically the conditionality of the vouchers, balance, and household characteristics at baseline. Section 4.1 reports impacts on overall demand for titles (i.e. the extensive margin) and Section 4.2 reports the results for co-titling (i.e. the intensive margin). Section 4.3 presents heterogenous effects and additional discussion of the main results and Section 5 concludes.

\section{Background and context}

\subsection{Female land ownership: empirical literature and Tanzanian law}

One of the main aims of this paper is to investigate whether Tanzanian households can be induced to grant formal land ownership rights to women. The Tanzanian government's ongoing efforts to formalize land tenure ignores this gender dimension, raising the possibility that current policy will also formalize de facto land ownership arrangements which are heavily skewed in favor of men. This section reviews both the general empirical literature and Tanzanian law to anticipate whether movements from informal land tenure to (a) formal property rights in general and (b) women's ownership or co-ownership in particular will lead to improvements in both female and household welfare.

We first consider the state of women's ownership under informality, which in Tanzania remains unclear from a legal standpoint. The 1999 Land Act was hailed as being one of the first pieces of land legislation to explicitly recognize the rights of women as landowners and contains several provisions granting ownership rights to women who co-reside with their husbands (Sundet 2005). However these legal reforms do not appear to have fully translated into perceived ownership rights: as part of the baseline data collection for this experiment, households in the unplanned settlements of Dar es Salaam were asked a series of questions about the de facto ownership of land, including the rights of household 
members over the sale, rental and transfer of land, as well as who would be included in an application for a CRO application if one was made. Table 1 displays the results, restricted to dual-headed households, which suggest that women currently have limited de facto rights over land: roughly $13 \%$ of households report that a woman is one of the "default" owners of the land. Women fare a little (but not much) better in 'use' rights, with just over $40 \%$ of households reporting that at least one woman in the household must agree before the land can be sold, transferred or rented out. ${ }^{3}$

These low levels of self-reported ownership are disconcerting: several studies find a correlation between improvements in women's de facto property rights with other desirable outcomes such as measures of female empowerment, child health, education and women's welfare - though causal inference is not always clearly established. For example, self-reported ownership of land is positively correlated with child health status and various measures of empowerment in Nepal (Allendorf 2007) and with expenditure on 'gendered' goods in both China and Ghana (Wang 2011; Doss 2005). Recent work by Doss, Kim, Njuki, Hillenbrand, and Miruka (2014) reveals that, in Tanzania, women who report joint-ownership of land are more involved in household decision-making.

Given the relatively low levels of de facto ownership, would we expect full formalization to be advantageous to women and others in their households? There is growing international evidence that formal land titling can be advantageous to women, irrespective of their state of ownership. Using data from a Peruvian titling program with a distinct focus on joint-titling, Field (2003) demonstrated a link between title acquisition and subsequent reduction in household fertility, where Wiig (2013) demonstrated a positive impact on the role of women's decision-making in the household. Galiani and Schargrodsky (2010) show that titling in Buenos Aires resulted in a reduction in household size and higher levels of child education. Evidence from Rwanda has also shown that titling programs can be successful at increasing perceived female ownership and the recording of inheritance rights (Ali, Deininger, and Goldstein 2011). Although many of these studies involve joint-titling programs, few are able to distinguish the additional impact of joint-titling (co-titling) from the overall impact of titling. The few studies which have attempted this have relied mainly on panel data, finding some evidence that co-titling or sole-female ownership has positive impacts on schooling but no impacts on productivity (Menon, van der Meulen Rodgers, and Nguyen 2014; Newman, Tarp, and van den Broeck 2015).

Would the potential gains associated with titling and co-titling manifest in Tanzania? Even when land titles have been issued in the male spouse's name only, the Land Act grants women ownership status when they invest in or maintain the land in question, as

\footnotetext{
${ }^{3}$ To avoid priming, households were not asked directly about female ownership. Instead, they were asked to list all members of the household that were default owners, must be consulted before a sale, or would be included on a CRO.
} 
well as giving them rights to block the sale or mortgage of land. However, the Land Act conflicts with older, more established pieces of legislation like the 1971 Law of Marriage act which stipulates that property assigned solely to one spouse cannot be claimed by the other later on. ${ }^{4}$ As a result, it remains unclear whether or not women's rights are actually binding in a de jure sense. Although the move from informal to formal sole male ownership does not necessarily weaken women's claims to lands (and might, under some circumstances, improve it), evidence to date implies that households tend to cement the status quo during formalization. For instance, in the property register maintained by the Kinondoni municipality in Dar es Salaam, approximately $70-75 \%$ of all land registered with a residential license is done so with a single male name. ${ }^{5}$ Similarly, when households in our study sampled were asked who would be included on a full title if they applied for one, only $25 \%$ mentioned a women as one of the owners (Table 1).

By contrast, when women are granted co-ownership of the land as part of the titling process the Land Act is quite explicit about the legal rights they have. Co-owners (or occupiers-in-common as they are known) have veto powers over all forms of land dispensation $^{6}$, and because the women has been named as an owner of the property, there is no longer any conflict with the Law of Marriage Act. What is less clear is whether or not co-titling improves the de facto state of women's ownership relative to that of male-titling or informality, a question this experiment ultimately aims to answer. In the next subsection, we discuss how existing barriers to obtaining title in urban Tanzania give us scope to experimentally vary both access to formal land titles both across and within households.

\subsection{The cost of formalization in Tanzania}

The land tenure formalization program in Tanzania was directly shaped by the work of Hernando de Soto, who emphasized that formalization would unlock the "dead capital" of the informal sector, providing a catalyst to economic development (Sundet 2006). Former Tanzanian president Benjamin Mkapa (1995-2005) invited De Soto to Tanzania to help establish a "Property and Business Formalisation Programme", known by its Swahili acronym, MKURABITA. The core aim of the program was to impart to the poor both business registration and formal titles which would be freely tradable and usable as collateral for accessing formal credit (Sundet 2006).

While MKURABITA remains active, the roll-out of land titles to the poor has been extremely limited. Even in urban areas, the proportion of land covered by a formal title that is transferrable and usable as collateral in the formal credit market is less than $15 \%$, and the share of actual parcels covered is considerably smaller. One likely explanation is

\footnotetext{
${ }^{4}$ Section 191(2) of the 1999 Land Act and section 58 of the (1971) Law of Marriage Act.

${ }^{5}$ Authors' calculations using data from the Kinondoni municipal data.

${ }^{6}$ Section 159(6) of the 1999 Land Act.
} 
Table 1: Female land ownership in Dar es Salaam

\begin{tabular}{lccc}
\hline \multicolumn{1}{c}{ Variable } & Mean & (Std. Dev.) & N \\
\hline One of default owners is female & 0.131 & $(0.337)$ & 605 \\
Woman has rights over land sale & 0.448 & $(0.498)$ & 601 \\
Woman has rights over transfer & 0.436 & $(0.496)$ & 601 \\
Woman has rights over rental & 0.419 & $(0.494)$ & 601 \\
Household would include woman on CRO & 0.252 & $(0.435)$ & 599 \\
\hline
\end{tabular}

Notes: data are from Tanzanian Land Rights survey (baseline). Sample restricted to dual-headed households in treatment blocks.

that the exorbitantly high costs of formalization, driven by expensive requirements and survey standards, have placed titles out of the reach of the majority of the urban poor.

From a research perspective, the current situation in Tanzania, where households have a legal right to titles but cannot afford them, provides scope to experimentally vary access to titles by subsidizing the price faced by households. Furthermore, there are considerable economies of scale in formalization, making it cost effective for a development project to offer titles at discounted prices to a large number of households.

Cadastral surveying is currently the largest single cost of land tenure formalization. Economies are due in part to simple geometry: beacons placed at the corners of one parcel can double as markers for adjacent parcels. ${ }^{7}$ In addition, the administrative processes associated with cadastral surveying, from consulting with local community leaders to filing papers with the relevant local and central government officials, can be done en masse with considerable cost savings.

Interviews with multiple surveying companies in Dar es Salaam produced cost estimates for surveying a single parcel ranging from approximately $\$ 600$ at the very low end to upwards of $\$ 3,000$ - depending on the size, location, and other complicating factors related to local government administration. The Tanzanian Ministry of Lands estimates systematic demarcation at scale costs approximately 150,000 to 250,000 shillings per parcel ( $\$ 96$ to $\$ 160$ ), though the basis for these estimates is somewhat opaque. For the purposes of this field experiment, the World Bank - in collaboration with the Ministry of Lands, the Dar es Salaam City Council, and the Kinondoni Municipality - contracted a private surveying company to produce a cadastral survey of the roughly 1,100 parcels in the treatment area. In addition, because of the large number of parcels affected, the project was also required to contract a certified town planner to produce a detailed map of future, purely hypothetical infrastructure investments in the area (including the boundaries of roads if paved, installation of electric street lights, public water pumps, etc.) that was approved by the Kinondoni Municipal Council. The combined cost of town planning

\footnotetext{
${ }^{7}$ In the simple case of rectangular parcels on a grid, surveying $n$ parcels requires $(\sqrt{n}+1)^{2} / n$ beacons. Obviously demarcating a single parcel requires four beacons. As $n$ increases, the number of beacons required per parcel approaches one.
} 
and surveying for the project was considerably below the Ministry's estimates, at roughly 70,000 shillings per parcel (approximately $\$ 45$ ).

Thus we were able to open up access to titles to a population which had previously, purely due to cost, been excluded from obtaining them. This, combined with the space for improvement in both observed and hypothetical co-titling rates (as displayed in Table 1), created an environment where experimental variation in price could be used to incentivize co-titling.

\section{Experimental design and data collection}

The setting for the main experiment is Kinondoni, one of the three municipalities constituting Dar es Salaam. We focus on two adjacent communities: Mburahati Barafu and Kigogo Kati are unplanned, informal settlements with markedly low levels of access to infrastructure and public utilities, even by the relatively low benchmark set by other communities in the municipality. Both of these mitaa also appear to have noticeably lower levels of female land ownership: investigating the gender breakdown of land ownership in the Kinondoni land registry reveals that Barafu and Kati have female ownership rates of $17 \%$ and $22 \%$ respectively, compared to the municipal average of $25 \%$.

The main purpose of the experiment was to induce households in both communities to purchase certificates of right of occupancy (CROs), in order to subsequently study their impact. This involved several levels of randomization:

1. Cadastral survey and repayment program: across the two communities, blocks of land parcels were identified and randomly selected into treatment and control groups. All parcels in treatment blocks were subject to cadastral surveying, with residents given the option to repay the heavily-subsidized cost (100,000 TSh) in exchange for a land title, drastically bringing down the cost of a CRO for residents. The control group was able to continue purchasing CROs at the full government price (including a cadastral survey, these households faced costs in excess of 500,000 Tsh). As no households in the control group went on to purchase CROs, we solely use data from the treatment groups in this paper.

2. Random price variation within treatment blocks: households within treatment blocks were randomly allocated up to two vouchers redeemable for different levels of discount on the final price of a CRO.

3. Random voucher conditionality: roughly half of these vouchers were made conditional, redeemable only if a female household member was included as an owner on the CRO application. Households could receive either a single normal or conditional voucher, one of each, or neither. 
Next, we will discuss these interventions in more detail, including the timing of their introduction in both communities.

\subsection{Main intervention and voucher distribution}

In the summer of 2010, prior to the intervention, the University of Oxford conducted a complete census of land parcels in Barafu and Kati, known as the Tanzanian Land Rights Survey (TLRS). Households were identified using records and maps from the Kinondoni Municipality, which had created a listing of all households in the area to assist with the creation of the land registry. Using this listing, parcel-owning households were identified and interviewed, resulting in detailed data on household and parcel characteristics, which we will refer to as baseline data for the rest of the paper.

Following this survey, a ward-level meeting was held by a local NGO, the Women's Advancement Trust (WAT), to explain the overall intervention and process of selection into treatment and control blocks. Using a town plan recently drawn up as a prerequisite for CRO distribution, we then divided land parcels into fifty 'blocks' (contiguous groups of parcels), randomly assigning half of these into treatment and control groups. ${ }^{8}$ All parcels in treatment blocks were subject to a cadastral survey and owning households were invited to participate in the program to obtain a land title, which required them to repay the cost of 100,000 TSh over roughly a six month period. ${ }^{9}$

The second and third dimensions of the intervention were cross-cutting and randomized at the individual parcel level within treatment blocks. After treatment parcels were selected, owners were to be given up to two types of discounts on the price of a CRO, both redeemable at WAT's office. The first type was an unconditional voucher, a simple discount on the 100,000 TSh price. The second was a conditional voucher, which could only be applied if one of the names registered on the CRO application form was a female household member. These conditions were carefully explained in Swahili on each type of voucher. If households elected to use a conditional voucher, names were checked at the time of application to ensure compliance with the requirements. Vouchers were assigned to a parcel, rather than to a particular owner, so as to remain impartial to the identity of the actual owner within the household and to prevent vouchers from being exchanged between households. Examples of the vouchers can be seen in Figure 3 in the appendix.

Vouchers could take on values ranging from zero to 80,000 TSh, in iterations of 20,000, so households could face subsidies between $0 \%$ and $80 \%$ of the total cost of a CRO. This variation will be crucial for our ability to estimate the price-elasticities of demand for

\footnotetext{
${ }^{8}$ For Barafu, the total number of blocks was 20, for Kati it was 30 . The total number of treated parcels was 1,148 , with 1,135 in the control group.

${ }^{9} 100,000$ Tsh was equivalent to approximately 67 USD in nominal terms around the time of the intervention.
} 
Table 2: Intended general and actual gender-specific discount distributions

\begin{tabular}{|c||c|c|c|c|c||c|}
\hline \multicolumn{1}{|c||}{ General } & \multicolumn{7}{c|}{ Conditional Discount } \\
\hline Discount & 0 & $20 \mathrm{k}$ & $40 \mathrm{k}$ & $60 \mathrm{k}$ & $80 \mathrm{k}$ & Total \\
\hline \hline 0 & $6.7 \%(6.4)$ & $6.7 \%(8.1)$ & $6.7 \%(6.6)$ & $6.7 \%(7.1)$ & $6.7 \%(9.7)$ & $33.3 \%(37.9)$ \\
\hline $20 \mathrm{k}$ & $6.7 \%(7.7)$ & $6.7 \%(5.3)$ & $6.7 \%(7.4)$ & $6.7 \%(6.4)$ &. & $26.7 \%(26.82)$ \\
\hline $40 \mathrm{k}$ & $6.7 \%(6)$ & $6.7 \%(6.3)$ & $6.7 \%(6.6)$ & $\cdot$ &. & $20.0 \%(18.9)$ \\
\hline $60 \mathrm{k}$ & $6.7 \%(4.6)$ & $6.7 \%(4.9)$ &. &. &. & $13.3 \%(9.49)$ \\
\hline $80 \mathrm{k}$ & $6.7 \%(7)$ & $\cdot$ & $\cdot$ & $\cdot$ &. & $6.7 \%(7)$ \\
\hline \hline Total & $33.3 \%(31.7)$ & $26.7 \%(24.7)$ & $20.0 \%(20.5)$ & $13.3 \%(13.5)$ & $6.7 \%(9.7)$ & $100 \%$ \\
\hline
\end{tabular}

The baseline price was TSh. 100,000 for a CRO, per parcel, regardless of size or other characteristics.

Each cell shows the intended bivariate distribution of assignment to each combination of general and gender-specific discounts. Actual realized distributions (in percentages) for each cell are listed in ().

Blank cells were not used to avoid offering a negative net price. Actual distributions are calculated over sample for which baseline data is available.

both unconditional and conditional 'prices' of CROs. As shown in Table 2, every feasible combination of vouchers was given equal weighting in the randomization. ${ }^{10}$

These vouchers were presented to households from treated blocks at block-level information sessions, after a short presentation by WAT about the benefits of CRO ownership and co-titling. ${ }^{11}$. If no representative from the household was presented at the meeting, the voucher was delivered to them at a later date via a courier.

While there were ex-ante concerns that a randomized top-down voucher allocation might be perceived as unfair by participants, block-level public lotteries were deemed to be too impractical and problematic for ensuring balance and compliance. To balance these two concerns, we performed the voucher randomization in the following manner for each block:

1. We randomly drew a distribution of general/conditional voucher pairs, repeating the draw 100 times.

2. Balance was then tested for each draw using a vector of observable parcel-level characteristics and the three draws that were the most balanced (defined by average t-stat values) were kept.

3. These three outcomes were then presented to residents at the block-level information sessions. Each attendee was made aware of the three possible distributions, each labeled with a designated number. One of the attendees was selected by the rest to draw a number out of a hat, each number corresponding to a voucher distribution outcome. Whichever number was chosen determined the draw that would be used for the voucher distribution.

\footnotetext{
${ }^{10}$ The net price of a title was restricted to be strictly greater than zero, so any voucher combination which would violate this restriction was excluded from the randomization.

${ }^{11}$ Despite this, meeting attendance does not appear to predict co-titling behavior.
} 
Thus we were able to maintain control over the broad aspects of the randomization while still allowing residents some perceived agency in choosing the outcome. Following the voucher distribution, households were free to sign up with WAT and begin repayment.

Both the block and the parcel-level randomizations in Barafu and Kati were performed at different times and thus represent independent draws. Due to delays in the government provision of the maps necessary to identify treatment and control households, the program was first introduced in Barafu in late 2010, but not in Kigogo Kati until approximately a year later. One consequence of this difference in timing, as discussed in the next subsection, is that household survey data could be matched to parcel maps by the time of randomization in Kigogo Kati, allowing a richer set of controls there, whereas in Barafu balance was enforced based on the restricted set of parcel attributes available from the town plan.

In Barafu, block-level information and voucher sessions were held in late October, 2010, with participating landowners paying their net price to WAT between November and the summer of 2011. Following repayment, landowners in Barafu have been filling out and turning in CRO applications, to then be checked and sent on to the local government by WAT. In Kigogo Kati, the voucher sessions were held in early November, 2011, with repayment continuing until the summer of 2012. Due to excessive flooding in Kati, overall participation and take up has been significantly lower than in Barafu. The data presented in this paper comprises the latest take up and application data made available from the project. As the experimental variation in price was only generated within treatment blocks, the analysis in this paper is restricted to households in these blocks.

The intention of the experimental design was to eventually evaluate the impact of CRO ownership on a range of household and parcel outcomes, as well as investigate the impact of co-titling on female bargaining power. However, as the program proceeded in 2012 following the initial repayment drives in Barafu and Kati and cadastral surveying in the former, two policy decisions by the Tanzanian government led to a delay in the production of titles for both communities. First, the Ministry of Lands drastically raised the price faced by the NGO to process the applications, a price that the NGO itself was responsible with bearing. Second, following large-scale flooding in the city in late 2011, the Ministry of Lands decided to re-zone much of the study area as ineligible for title, despite initially agreeing to facilitate the project. As a result, to date, no titles have been issued in either community and the project has begun offering the residents the opportunity to withdraw any contributions made towards a CRO (with interest).

As we will describe later in the paper, the fact that a significant share of landowners in each community paid cash towards a CRO indeed indicates that households took this as a serious commitment to purchasing a CRO. Neither the NGO, the residents, or the researchers anticipated that a change in government policy would complicate this decision. 
This does, however, explain why take-up rates did not increase substantially following the initial payment period in 2010 and 2011 and why a number of households have yet to fill out an application. In order to ensure that the take-up measure we employ represents a credible commitment to purchase a land title, throughout this paper we will rely on resident's decision to fully pay for a CRO (or not) as a conservative measure of take-up, treating those who paid only in part as non-applicants.

\subsection{Balance and summary statistics}

Table 3 shows summary statistics for a select group of baseline characteristics taken from the 2010 survey, as well as a series of balance tests. These data are available for nearly all of the households in the experiment, as the more recent town planning maps used for the randomization could not be perfectly matched to the original maps used for the survey. Thus, baseline data is only available for a subset (1028) of households, although the results in this paper are robust to their inclusion/exclusion. ${ }^{12}$ To test whether there is a significant correlation between assigned voucher values and baseline characteristics, we estimate the following specification for each characteristic using ordinary least squares:

$$
x_{i}=\alpha_{0}+\alpha_{G} v_{G i}+\alpha_{C} v_{C i}+\varepsilon_{i}
$$

where $x_{i}$ is the characteristic of interest, $v_{G}$ is the general voucher value, and $v_{C}$ is the conditional voucher value, both expressed as a proportion of the total 100,000 Tsh price of a CRO (e.g. $v_{C i}=0.2$ indicates a 20,000 TSh voucher). We repeat the same exercise replacing the individual voucher values $\left(v_{G}\right.$ and $\left.v_{C}\right)$ with the net price $p_{i}$ expressed as a proportion of the total possible 100,000 TSh price. While it is more common to test the bivariate relationship between baseline characteristics and a single treatment, this method most-closely approximates the specification we will be using in the next section. Furthermore, as general and conditional voucher values were drawn as part of a joint distribution, it is more appropriate to test for the partial correlation between each voucher value while holding the other constant.

In Table 3, column (1) shows the mean and standard deviation for each baseline characteristic. First we test for balance across parcels with and without baseline data. Following this, the next five of these (marked with a $*$ ) represent characteristics that were available from the town plan and purposefully balanced at the time of the randomization in Barafu. This set of characteristics used for balance purposes in the experimental design was expanded in Kigogo Kati, based on matched survey data, to further include whether the household is Muslim (a possible proxy for female bargaining power), monthly income

\footnotetext{
${ }^{12}$ More importantly, there is no significant interaction between the availability of baseline data and the effects of the vouchers
} 
and total assets, the household's average schooling and size, whether the household owned a residential license, whether the parcel was inherited and whether it had a flush toilet. These characteristics are marked with a $\uparrow$ for clarity. Following Bruhn and McKenzie (2009), we control for this full set of variables used in re-randomization in the empirical specifications of this paper. ${ }^{13}$ We also show these results to be robust to the exclusion of all controls.

In addition to variables used in the re-randomization, and, consequently, as controls in the analysis of this paper, Table 3 also shows the distribution of other household characteristics of interest, particularly insofar as they measure female empowerment. These include the year the parcel was acquired, whether or not there has been investment in the parcel in the past year, whether the household is a single-female headed household, whether a woman in the household has any use rights, whether or not there is a default female owner, if the household would hypothetically include the woman on a CRO, and the percentage of total household income contributed by the female household head.

Columns (2) and (3) show estimates of $\alpha_{G}$ and $\alpha_{C}$, respectively. Column (4) displays the point estimate of a bivariate regression of the baseline characteristic on the net price faced by the household $\left(100-v_{G}-v_{C}\right)$. In general, there is good balance across the range of baseline characteristics. There are a few significant differences: households with a higher likelihood of having access to electricity had higher general and conditional voucher values. Inherited parcels and households with high levels of assets were assigned slightly lower general and conditional voucher values, respectively. ${ }^{14}$ There is also a slight lack of balance between household size, parcel size, the female household head's share of income. For column (5), we regress each outcome measure on a set of dummies for every possible voucher combination, then conduct a joint test of equality between these values. This column displays the $\mathrm{p}$-value from that $\mathrm{F}$-test, indicating generally good balance. We conduct more tests on balance across different combinations of voucher values in Table 8 in the appendix.

On the whole, where there is imbalance the differences are small, but do imply that those used for re-randomization should be used as control in the main specification. In the next section, we will include these particular baseline characteristics as controls. ${ }^{15}$

\footnotetext{
${ }^{13}$ We conducted re-randomization using variables derived from a combination of town plans and survey data in each community. The set of variables used in the two communities was overlapping, but not identical because our access to town plans differed. While the survey instrument was identical in the two communities, characteristics measured by the two town plans may have measured characteristics differently. In Table 3, we present variables used in re-randomization that are available from the survey data, which we can confidently claim are comparably measured across the two samples. Thus we exclude from the set of controls some baseline variables that were not measured in the survey data, but were only measured in one community or the other, or perhaps measured in ways that were not entirely comparable across the two communities.

${ }^{14}$ It is worth noting that the imbalance in assets does not appear for $\log$ (assets).

${ }^{15}$ Our measures of the year the parcel was bought and of recent investment are not used here as controls, but the results are robust to their inclusion. The final three variables which cover women's empowerment will be used in Section 4.3.
} 
Table 3: Summary statistics and balance

\begin{tabular}{|c|c|c|c|c|c|}
\hline & $\frac{\text { Mean/SD }}{(1)}$ & $\frac{\text { General }}{(2)}$ & $\frac{\text { Conditional }}{(3)}$ & $\frac{\text { Price }}{(4)}$ & $\frac{P \text {-val }}{(5)}$ \\
\hline Baseline data available & $\begin{array}{l}0.899 \\
(0.302)\end{array}$ & $\begin{array}{l}-.024 \\
(0.041)\end{array}$ & $\begin{array}{l}-.055 \\
(0.037)\end{array}$ & $\begin{array}{l}0.042 \\
(0.032)\end{array}$ & 0.421 \\
\hline HH lives on parcel* & $\begin{array}{l}0.798 \\
(0.424)\end{array}$ & $\begin{array}{c}0.03 \\
(0.062)\end{array}$ & $\begin{array}{l}0.055 \\
(0.055)\end{array}$ & $\begin{array}{l}-.044 \\
(0.051)\end{array}$ & 0.587 \\
\hline Parcel is rented out* & $\begin{array}{c}0.39 \\
(0.515)\end{array}$ & $\begin{array}{l}-.107 \\
(0.071)\end{array}$ & $\begin{array}{l}-.062 \\
(0.067)\end{array}$ & $\begin{array}{c}0.082 \\
(0.06)\end{array}$ & 0.428 \\
\hline Electricity access?* & $\begin{array}{l}0.401 \\
(0.517)\end{array}$ & $\begin{array}{c}0.143 \\
(0.072)^{* *}\end{array}$ & $\begin{array}{c}0.143 \\
(0.067)^{* *}\end{array}$ & $\begin{array}{l}-.143 \\
(0.06)^{* *}\end{array}$ & 0.043 \\
\hline Log $\left(\text { Parcel Area } m^{2}\right)^{*}$ & $\begin{array}{l}5.110 \\
(0.58)\end{array}$ & $\begin{array}{l}-.153 \\
(0.084)^{*}\end{array}$ & $\begin{array}{l}-.063 \\
(0.077)\end{array}$ & $\begin{array}{l}0.103 \\
(0.069)\end{array}$ & 0.067 \\
\hline Number of HH's in block* & $\begin{array}{c}47.029 \\
(5.680)\end{array}$ & $\begin{array}{l}0.036 \\
(0.744)\end{array}$ & $\begin{array}{l}-.912 \\
(0.754)\end{array}$ & $\begin{array}{l}0.495 \\
(0.644)\end{array}$ & 0.32 \\
\hline Monthly income (tsh '000) ${ }^{\dagger}$ & $\begin{array}{l}389.020 \\
(693.115)\end{array}$ & $\begin{array}{c}-95.309 \\
(96.037)\end{array}$ & $\begin{array}{c}-82.835 \\
(75.035)\end{array}$ & $\begin{array}{l}88.316 \\
(71.431)\end{array}$ & 0.296 \\
\hline Total assets $\left(\text { tsh }{ }^{\prime} 000\right)^{\dagger}$ & $\begin{array}{l}3623.516 \\
(5809.450)\end{array}$ & $\begin{array}{c}-1364.174 \\
(713.787)^{*}\end{array}$ & $\begin{array}{c}-480.243 \\
(772.946)\end{array}$ & $\begin{array}{l}868.623 \\
(649.102)\end{array}$ & 0.648 \\
\hline Average schooling of $\mathrm{hh}^{\dagger}$ & $\begin{array}{c}12.221 \\
(2.911)\end{array}$ & $\begin{array}{l}-.248 \\
(0.395)\end{array}$ & $\begin{array}{l}-.279 \\
(0.393)\end{array}$ & $\begin{array}{l}0.265 \\
(0.345)\end{array}$ & 0.678 \\
\hline Household size ${ }^{\dagger}$ & $\begin{array}{l}5.053 \\
(2.719)\end{array}$ & $\begin{array}{c}0.661 \\
(0.364)^{*}\end{array}$ & $\begin{array}{l}0.331 \\
(0.335)\end{array}$ & $\begin{array}{l}-.476 \\
(0.293)\end{array}$ & 0.22 \\
\hline Muslim household ${ }^{\dagger}$ & $\begin{array}{l}0.568 \\
(0.523)\end{array}$ & $\begin{array}{l}-.041 \\
(0.073)\end{array}$ & $\begin{array}{l}-.041 \\
(0.068)\end{array}$ & $\begin{array}{l}0.041 \\
(0.061)\end{array}$ & 0.152 \\
\hline Households owns an $\mathrm{RL}^{\dagger}$ & $\begin{array}{l}0.474 \\
(0.527)\end{array}$ & $\begin{array}{l}-.034 \\
(0.071)\end{array}$ & $\begin{array}{l}0.025 \\
(0.068)\end{array}$ & $\begin{array}{c}0.0006 \\
(0.06)\end{array}$ & 0.118 \\
\hline $\mathrm{HH}$ has no flush toilet ${ }^{\dagger}$ & $\begin{array}{c}0.83 \\
(0.397)\end{array}$ & $\begin{array}{l}-.071 \\
(0.054)\end{array}$ & $\begin{array}{l}-.047 \\
(0.051)\end{array}$ & $\begin{array}{l}0.058 \\
(0.045)\end{array}$ & 0.489 \\
\hline Parcel was inherited $^{\dagger}$ & $\begin{array}{l}0.111 \\
(0.331)\end{array}$ & $\begin{array}{l}-.033 \\
(0.048)\end{array}$ & $\begin{array}{l}-.071 \\
(0.041)^{*}\end{array}$ & $\begin{array}{l}0.054 \\
(0.039)\end{array}$ & 0.381 \\
\hline Year parcel was acquired & $\begin{array}{c}1992.478 \\
(13.585)\end{array}$ & $\begin{array}{l}-.879 \\
(1.726)\end{array}$ & $\begin{array}{l}-2.537 \\
(1.864)\end{array}$ & $\begin{array}{l}1.808 \\
(1.505)\end{array}$ & 0.66 \\
\hline Recent investment in parcel & $\begin{array}{l}0.212 \\
(0.431)\end{array}$ & $\begin{array}{l}0.046 \\
(0.057)\end{array}$ & $\begin{array}{l}0.081 \\
(0.055)\end{array}$ & $\begin{array}{l}-.066 \\
(0.047)\end{array}$ & 0.013 \\
\hline Woman has rights over sale & $\begin{array}{l}0.582 \\
(0.594)\end{array}$ & $\begin{array}{l}-.043 \\
(0.082)\end{array}$ & $\begin{array}{l}-.035 \\
(0.078)\end{array}$ & $\begin{array}{l}0.039 \\
(0.069)\end{array}$ & 0.954 \\
\hline De facto female owner & $\begin{array}{l}0.267 \\
(0.467)\end{array}$ & $\begin{array}{l}-.051 \\
(0.065)\end{array}$ & $\begin{array}{l}-.058 \\
(0.061)\end{array}$ & $\begin{array}{l}0.055 \\
(0.055)\end{array}$ & 0.958 \\
\hline Would hypothetically cotitle & $\begin{array}{l}0.356 \\
(0.509)\end{array}$ & $\begin{array}{l}-.043 \\
(0.07)\end{array}$ & $\begin{array}{l}0.002 \\
(0.067)\end{array}$ & $\begin{array}{l}0.018 \\
(0.06)\end{array}$ & 0.378 \\
\hline Women's share of hh income & $\begin{array}{l}0.309 \\
(0.547)\end{array}$ & $\begin{array}{c}-.102 \\
(0.077)\end{array}$ & $\begin{array}{c}-.117 \\
(0.071)^{*}\end{array}$ & $\begin{array}{c}0.11 \\
(0.064)^{*}\end{array}$ & 0.184 \\
\hline Obs & (1028) 1144 & & & & \\
\hline
\end{tabular}

Column (1) displays the mean and standard deviation for each variable. Columns (2)-(3) display the mean and standard error of $\alpha_{G}$ and $\alpha_{C}$ from the linear regression of each variable $v a r=\alpha_{0}+\alpha_{G} v_{G i}+\alpha_{C} * v_{C i}$, where $v_{G i}$ and $v_{C i}$ are the general and conditional voucher values for each parcel $i$, measured as a proportion of the default price of TSh 100k. Column (4) shows the results of a single bivariate regression of each variable on the overall price households faced net of all vouchers (as \% of TSh 100k). Column (5) shows the p-val resulting from a F-test of equality of all possible voucher combinations taken from a linear regression var $=\alpha_{0}+\sum_{i=1}^{14} \alpha_{G C} d_{G C i}$, that is, the baseline characteristic regressed on a series of dummies for each possible voucher combination. More detailed balance results are available in Table 8 in the appendix. Robust standard errors ${ }^{*}(p<0.10),{ }^{* *}(p<0.05),{ }^{* * *}(p<0.01)$ Observation count is 1144 for the top row and 1028 for all subsequent rows. ${ }^{*}$ characteristics used re-randomization in both communities. ${ }^{\dagger}$ used for re-randomization in only Kati (second community). 


\section{Results}

\subsection{Take-up}

In this section we aim to estimate the effect of conditional and unconditional price discounts on take-up, in order to investigate whether there is any tension between improving women's land ownership along the intensive margin and the extensive margin. Let $q_{i}$ be a binary indicator of whether household $i$ purchases a land title.

$$
q_{i}=\beta_{0}+\beta_{G} v_{G i}+\beta_{C} v_{C i}+\beta_{x} \mathbf{x}+\varepsilon_{i}
$$

In this equation, $v_{G i}$ and $v_{C i}$ are the levels of general and conditional vouchers allocated to the household, again both expressed as a proportion of the total 100,000 Tsh price of a CRO (i.e. taking on values between 0.2 and 0.8 ), and $\mathbf{x}$ is a vector of household characteristics measured at baseline which are included as controls to improve efficiency. The main hypothesis to be tested here is whether households place equal value on conditional vouchers, i.e., whether $\beta_{G}=\beta_{C}$. We expect to reject this null if there is disutility to (predominately male) household heads who would prefer not to include their spouses as co-owners. In such a case they would require a larger price subsidy in order to offset the prospect of, e.g., diminished bargaining power. A failure to reject the null would suggest that households are treating the implications of using conditional vouchers and general vouchers equally.

The results of estimating equation (2) are presented in columns (1)-(3) of Table 4. Because the variables are expressed as discounts rather than prices, we anticipate positive coefficients on these variables. In the first column, we estimate the above equation over all available observations in treatment blocks, then in subsequent columns we restricted to households in treatment blocks with baseline data available. ${ }^{16}$ Columns (2) shows the results from estimating equation (2) without controls, and and (3) with baseline socioeconomic controls.

Households appear to be equally responsive to conditional vouchers. At the bottom of Table 4, "Test 1" reports the p-value from the linear test of $\beta_{G}=\beta_{C}$, revealing that we can comfortably fail to reject the null that these two coefficients are equal across all specifications. ${ }^{17}$ The results here strongly suggest that households treat conditional vouchers as 'cash': that is, they do not appear to be any demand effects of imposing conditionality. This implies that, on average, gender conditionality can be imposed without excluding households averse to co-titling. Figure 1 displays estimated take-up levels for each voucher

\footnotetext{
${ }^{16}$ Households in control blocks were excluded from purchasing through the NGO, and local records suggest that none have gone on to purchase CROs through the municipal government.

${ }^{17}$ The failure to reject the null is not driven by imprecision, as the coefficients displayed here are precisely estimated.
} 
The pooling of these two voucher types provides prima facie evidence that progress on the intensive margin of female co-titling can be achieved with limited tradeoffs on the extensive margin, namely, whether households get a title at all. Given that these vouchers were distributed by an NGO with gender equity as part of its mission, it is important to consider whether the context and messaging of our intervention condition these effects. Three factors lead us to believe that this limited infra-extra-marginal tradeoff may apply in other settings as well. First, we note that all households received the same exposition of the program from the NGO, prior to and irrespective of their voucher status. So, the most obvious effect of this messaging is to expect some impact on the likelihood of co-titling at all voucher levels, even those who did not receive any conditional voucher. Second, one might be concerned that the NGO effectively required participants who received conditional vouchers to use them. However, we show in Appendix Table 10 that, while the fraction of households who use conditional vouchers is high (consistent with treating them like unconditional), there is a non-negligible share of households who purchase titles after receiving conditional vouchers, but fail to use them. And third, we think it unlikely that, if governments themselves or other partners were to implement such a scheme, it could be done without conveying a norm. In this respect some measure of messaging may be inextricably tied to the use of gender-conditional vouchers, and would also be a feature of programs that used this approach elsewhere.

type. While the pattern of take-up across each value differs slightly between general and conditional vouchers, tests of the average linear difference in Table 4's regression results fails to reject the null that they are the same.

The fact that conditional and unconditional vouchers appear to pool, (i.e., we cannot reject $\beta_{g}=\beta_{c}$ ) provides justification to combine these variables for the sake of improved power to explore additional hypotheses about the slope of the demand curve for land titles at the household level. We define the price of land title faced by a household, net of all discounts as the final price the household would have faced had they used all the vouchers on offer, again expressed as a proportion of the default 100,000 TSh price, so that $p_{i}=1-v_{G i}-v_{C i}$, and estimate the following alternative specification:

$$
q_{i}=\beta_{0}+\beta_{p} p_{i}+\beta_{x} \mathbf{x}_{i}+\beta_{p x}\left(p_{i} \times \mathbf{x}_{i}\right)+\varepsilon_{i}
$$

Results in columns (4) through (7) of Table 4 show that net price has, as expected, a significant negative effect on take-up. An increase in price of 10,000 shillings (10\% of the default CRO price) reduces the probability of buying a title by nearly $3 \%$, significant at the $1 \%$ level. This coefficient is essentially unchanged by the inclusion of socioeconomic controls. With no voucher discounts and a maximum price of 100,000 shillings, predicted take-up at mean values of the socio-economic controls is approaching $20 \%$. This rises to around $30 \%$ at a price of 60,000 shillings and nearly $45 \%$ at a price of 20,000 shillings. 


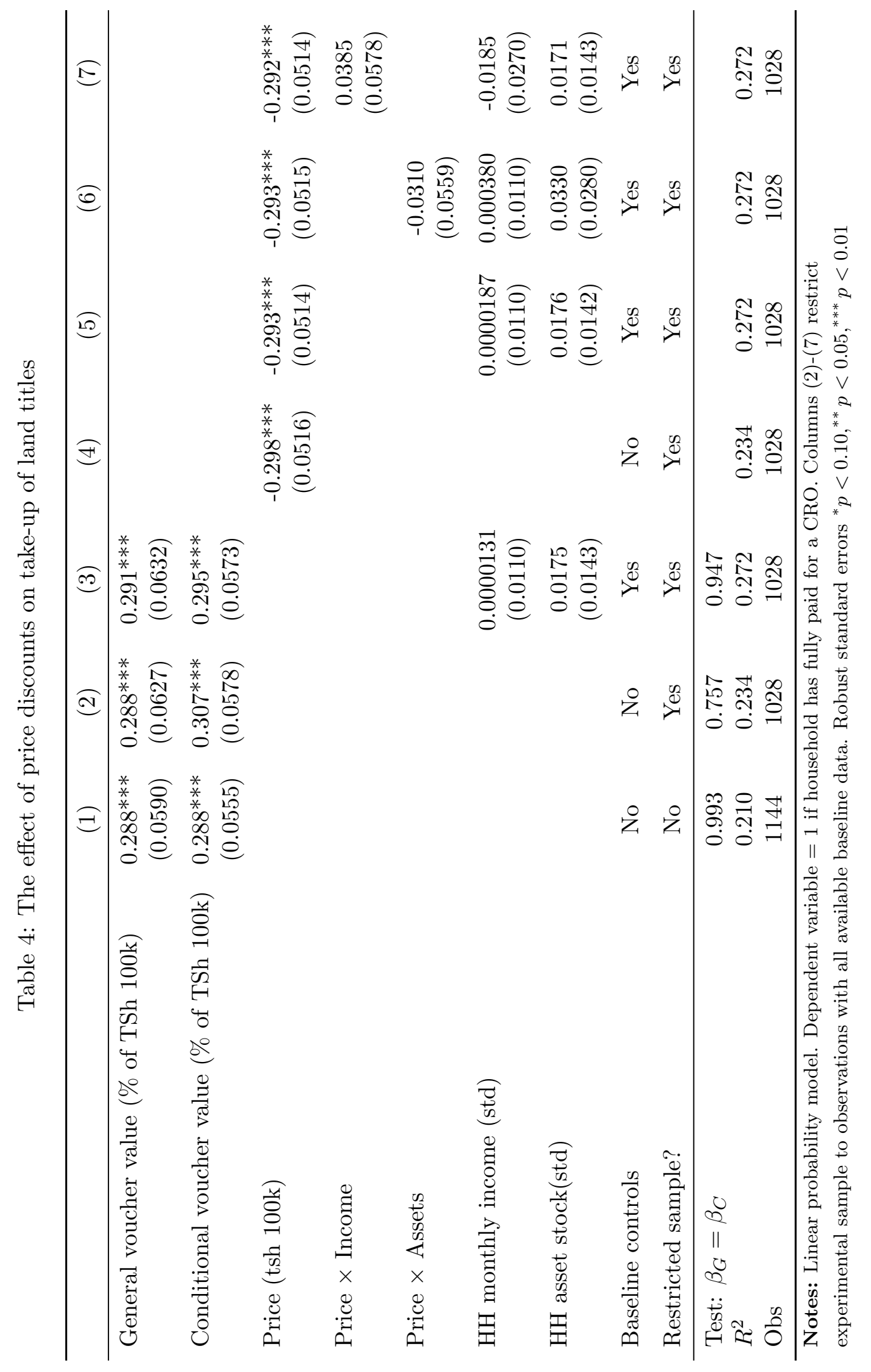


Figure 1: Voucher values and take-up rates

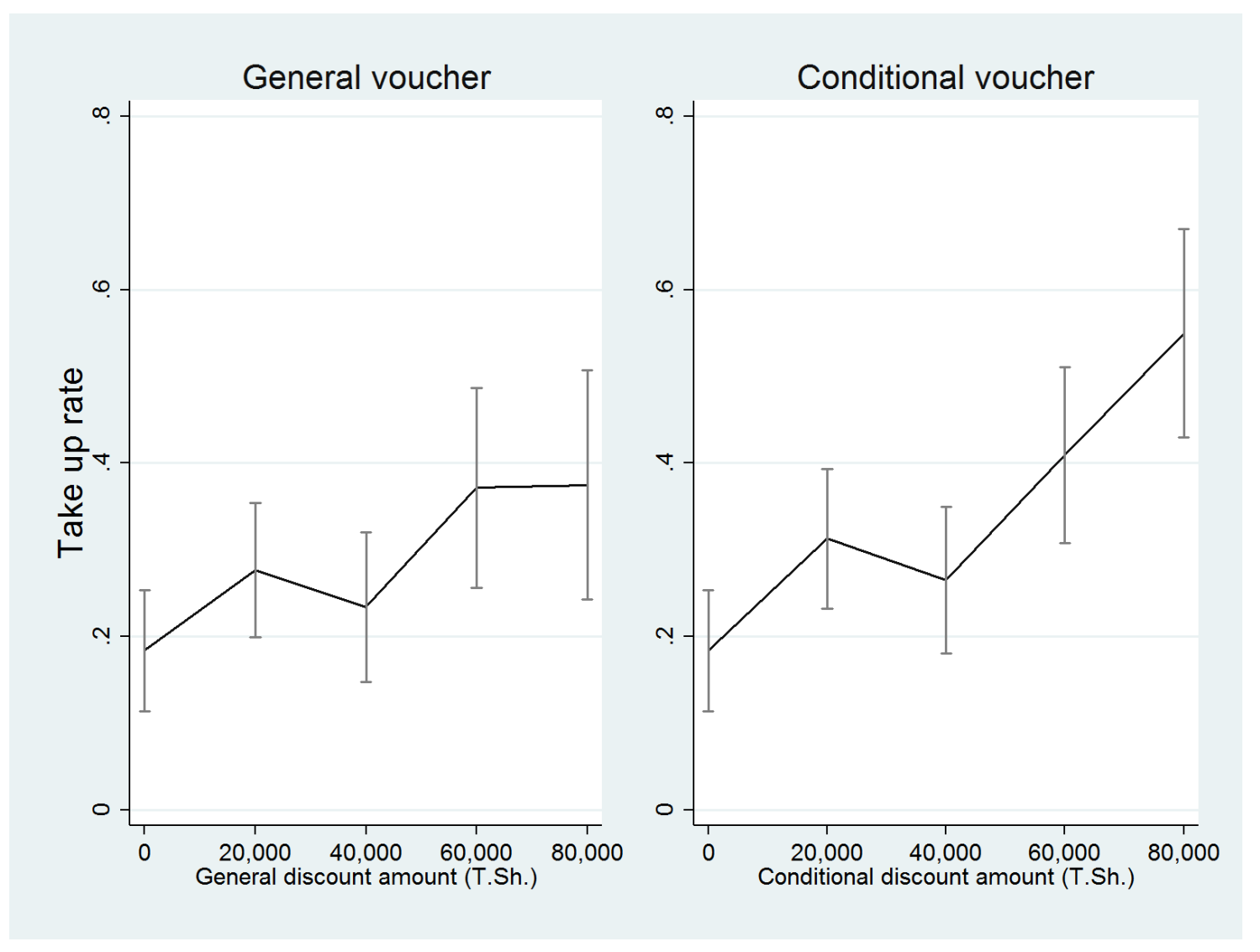

Figure shows estimates of take-up probability, conditioning on general conditional voucher values. Bars indicate $95 \%$ confidence intervals. 
Estimates of the effect of each voucher value on take-up that relax the linear functional form used here are available in Table 9 in the Appendix.

Land titles appear to be a normal good, but price sensitivity does not vary much by income. Column (3) of Table 4 shows that an increase of assets or income (at baseline) by one standard deviation increases take-up by less than $2 \%$ and less than $0.4 \%$ respectively, though neither are statistically significant. The interaction between price and either income or assets is entirely insignificant, with point estimates close to zero.

\subsection{Co-titling}

Encouragingly, the results in the previous subsection suggest that applying conditionality does not deter households from purchasing land titles, reducing concerns that it might be less effective in improving women's ownership along the extensive margin. However, this does not mean that households are more likely to register a female owner: they might be indifferent to listing women as owners or might have all planned to co-title irrespective of any conditionality. In this subsection, we seek to establish that price conditionality does encourage households to include women as landowners, indicating improvements along the intensive margin as well.

To investigate whether households respond to price incentives by co-titling, we rely on data from the household's CRO application, where women from the household were identified and recorded. Define cotitle $_{i}$ as a binary outcome equal to one if the household has included any woman from the household on the CRO application, conditional on the household having chosen to purchase a CRO. We then wish to re-estimate (2), using this variable as our outcome of interest:

$$
\text { cotitle }_{i}=\gamma_{0}+\gamma_{G} v_{G i}+\gamma_{C} v_{C i}+\gamma_{x} \mathbf{x}+\varepsilon_{i}
$$

Ideally, equation (4) should be estimated over the full sample of households who have chosen to purchase a CRO. However, to date approximately $25 \%$ of households who have finished payment on a CRO have yet to finish filling out an application, thus our analysis of application decisions covers a smaller number of households. ${ }^{18}$

Columns (1)-(3) of Table 5 show the results from estimating (4). Below the main results, 'Test' reports a linear test of the null hypothesis that the two vouchers have equal effects. The general voucher has no detectable effect on co-tilting, while the conditional

\footnotetext{
${ }^{18}$ While we will proceed as if the determinants of application choices being observable are random, it is possible that non-random selection of households choosing to fill out an application could lead to bias. Re-estimating (4) using a Heckman selection model (where whether or not the owning house was resident on the plot is used for the exclusion restriction) does not change the main results here These results, including the selection equation, are available in the Appendix.
} 


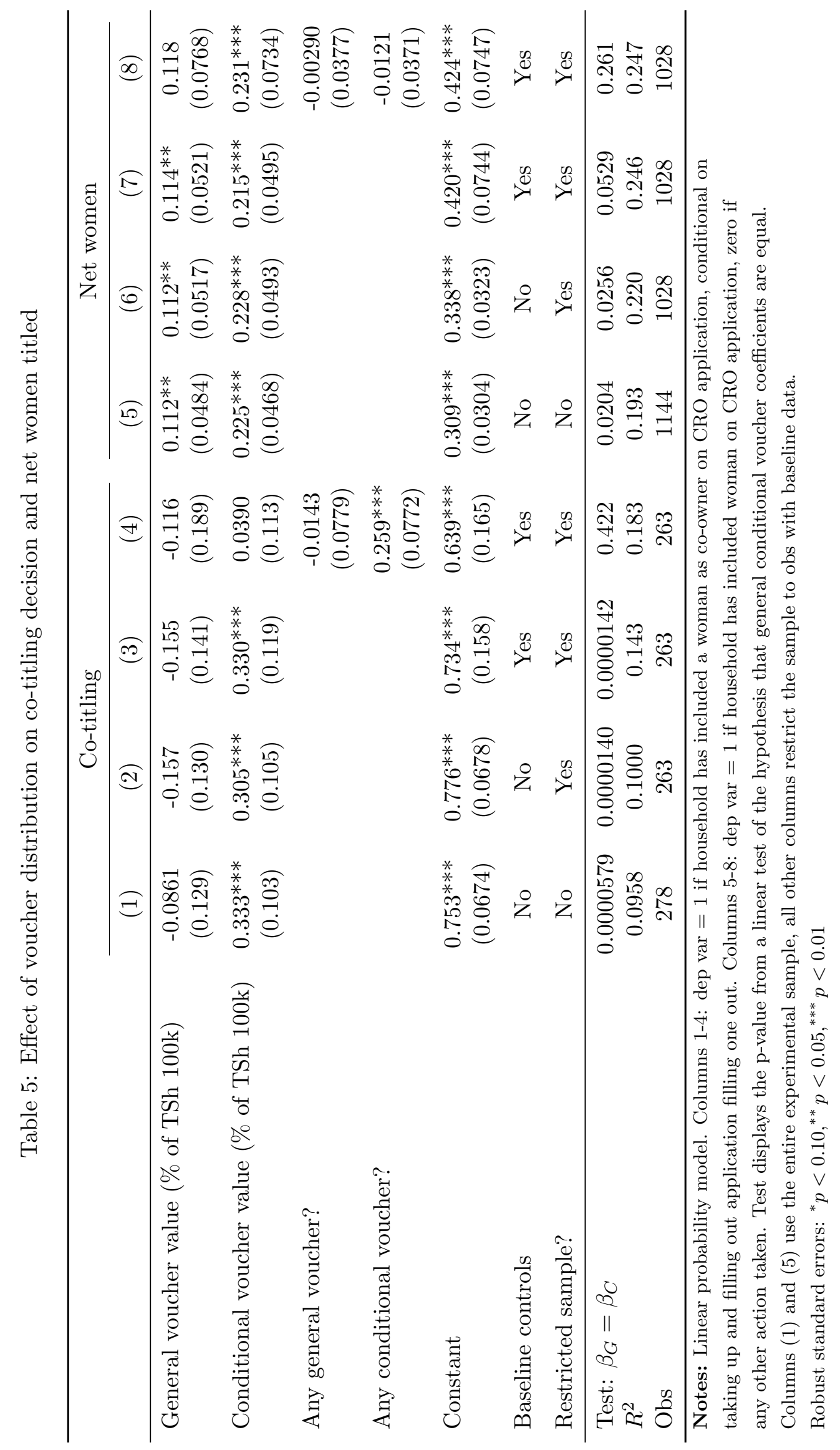


Figure 2: Voucher values and female co-title rates

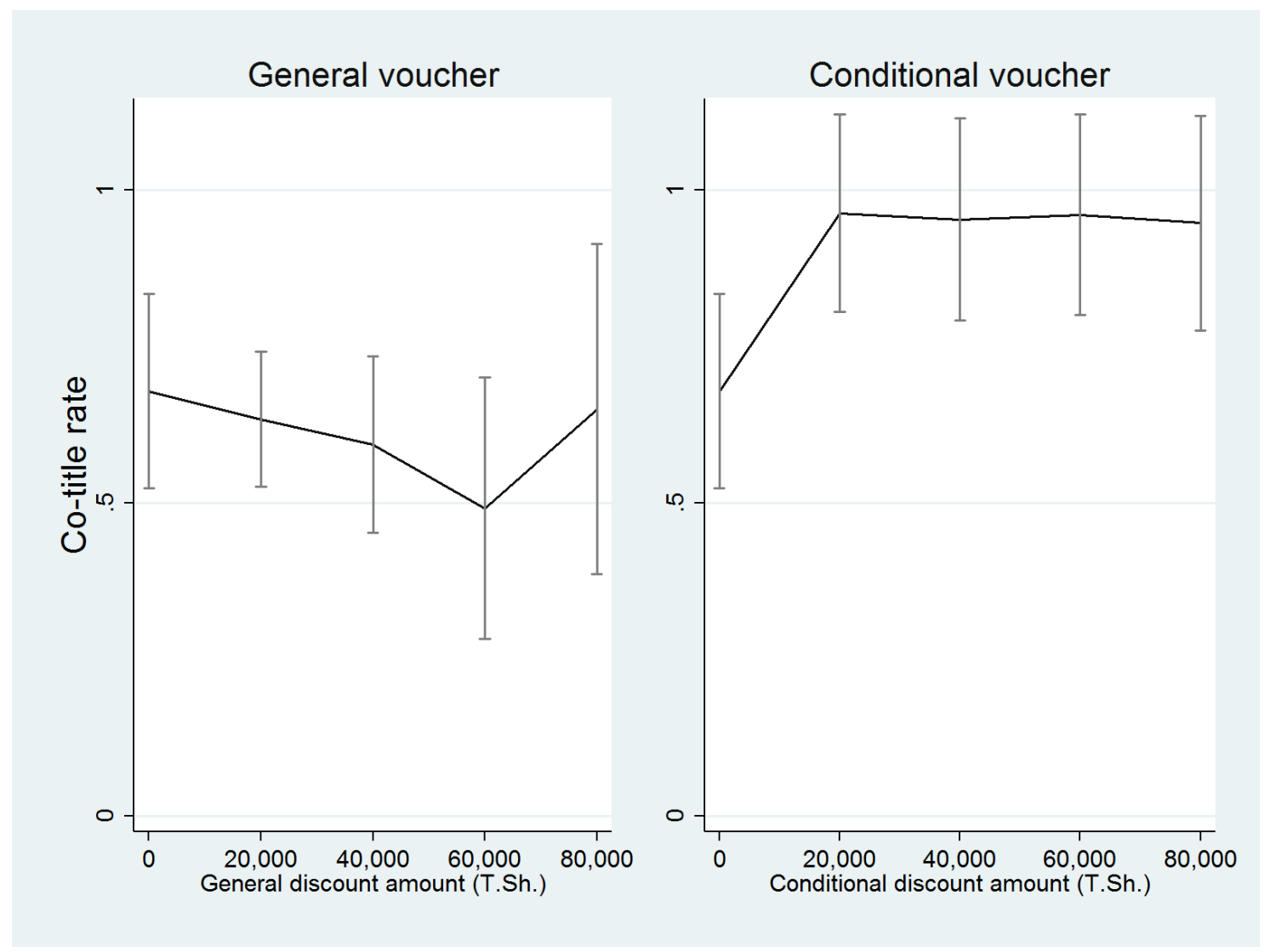

Note: Figure shows estimates of co-titling (conditional on submission of an application probability), conditioning on general/conditional voucher values. Bars indicate $95 \%$ confidence intervals. In a nonlinear specification where an indicator variable for each voucher value is included, for each positive conditional voucher value separately we can reject the null of no differential effect from no subsidy $\left(\gamma_{C}=0\right)$ or from the same general voucher value $\left(\gamma_{C}=\gamma_{G}\right)$. 
voucher has a positive and highly significant impact. The magnitude of this effect is fairly large: 10,000 TSh in subsidy (10\% of the default price) results in an increase in the predicted probability that a woman is included by 3.0-3.33 percentage points. According to these estimates, giving a parcel the largest conditional subsidy of $80 \%$ of the purchase price all but guarantees the household will co-title. An interesting and important feature of the results in Table 5 is the size of the constant term in columns (1)-(3). In the absence of any voucher discount, roughly $75 \%$ of buyers list a woman as co-owner on title application. This is compared to just $13 \%$ of households who report a woman as one of the owners of the parcel during the baseline survey. While this result is not not identified experimentally, it suggests a large, across the board increase in the demand for female co-titling as a result of the intervention. As noted above, the intervention was coordinated by a non-governmental organization strongly committed to promoting female empowerment, an organization founded and directed by a prominent female Tanzanian politician. The female ownership rights guaranteed under the 1999 Land Act are a core theme of the NGO's public activities. Thus the high levels of co-titling observed at all voucher values might be the result of the NGOs blanket efforts to promote co-titling. As all households received the same marketing pitch in favor of female ownership, this effect does not threaten the experiment per se, but it may place an upper bound on the size of the impact of conditional vouchers that we can detect. It is difficult to increase female co-titling rates when starting from such a high floor.

There is also some evidence that a linear specification (which was not rejected for the demand equation) may be too restrictive here. This is illustrated in Figure 2, where cotitling rates are graphed against voucher values. Households which receive any conditional voucher are approximately 25-30 percentage points more likely to co-title than those that receive no voucher (the omitted category). This is mirrored in the estimates displayed in column (4), where we include two dummy variables equal to one if the household has received any general voucher or any conditional voucher, respectively. This effect is persistent and statistically indistinguishable across all voucher values, indicating that households are effectively nudged into co-titling by even very small conditional vouchers. Vouchers unambiguously improve women's ownership along the intensive margin, as any household receiving a female voucher co-titles with close to $100 \%$ probability. The baseline co-titling rate falls between $60-65 \%$ in this nonlinear specification, substantially below the $75 \%$ rate seen in the linear specification. We show co-titling rates for every possible voucher combination in Table 10 in the Appendix.

\subsection{Discussion and heterogeneous effects}

The results so far imply that there is no tension between the intensive and extensive margin of improving women's formal ownership of land: conditional vouchers do not 
dissuade household from purchasing land titles but do induce them to include women as land owners. It follows that offering households conditional subsidies can only increase the total number of women on land titles.

To test this, we define an unconditional co-titling outcome, equal to one if the household purchases a CRO, submits an application and includes a woman as an owner on the application, and equal to zero if either the household submitted an application without including a woman or if they did not submit an application at all. We then repeat the standard specification with this "net co-titling" outcome to see if, in aggregate, conditional vouchers are more successful at moving households into a co-titled state. Columns (5)-(7) of Table 5 display the results. Again, below the main results, 'Test' reports a linear test of the null hypothesis that the two vouchers have equal effects, where we find the null is rejected at the $10 \%$ level in every test. While general vouchers have a small positive effect on the total number women listed on titles (operating purely through the extensive margin), conditional vouchers raise the number of women listed on titles by roughly twice as much. In summary, while the basic intervention was itself successful on improving the status quo, imposing conditionality dramatically increases the number of women listed as formal land owners.

The potential for welfare impacts may depend not only on these aggregate co-titling effects, but also from a welfare perspective, but also on their incidence. One might be concerned that the apparent efficacy of co-titling incentives is concentrated among households where female bargaining power is already strong: in such households, legal interventions may not substantially affect bargaining outcomes. To address this question of incidence, we examine heterogeneity in voucher impacts by measures of female bargaining power and de facto female ownership at baseline.

Table 6 re-estimates the three specifications used before (CRO take-up, conditional co-titling and net co-titling) with the sample restricted to households with at least one adult man and woman (henceforth, dual-headed households). ${ }^{19}$ We consider two dummy variables which might proxy for women's current bargaining power: whether or not a woman is considered a default owner of the property, and the share of total household income the female household-head provides. Column (1) shows the aggregate result for take-up and column (2) displays the same specification, but with interactions between the default owner dummy and both voucher values. The results indicate that properties where women are already considered co-owners are significantly less likely to adopt CROs, but are not significantly more or less responsive to voucher allocations, nor do they treat general or conditional voucher values differently. However, the picture changes when we observe conditional co-titling outcomes in column (3), where households with de facto female ownership are substantially more likely to co-title, but are not responsive to conditional vouchers. While conditional vouchers appear to still have a strong positive effect

\footnotetext{
${ }^{19}$ This sample allows us to focus on households where bargaining power is likely to be a concern.
} 
on households without default female ownership, a linear test cannot reject the hypothesis that the two vouchers have an equivalent impact for households with default ownership (Test 3 under column three). Column (4) displays the unconditional, net co-titling outcomes, indicating no substantial differences between households with de facto ownership in either average outcomes or responsiveness to vouchers.

Columns (5), (6) and (7) repeat this exercise, interacting the head's share of total household income with voucher values. Households in which women provide a greater share of household income are no less likely to purchase a CRO. There is also no concrete evidence that these households respond differently to either voucher. However, column (6) indicates households where women provide greater shares of income are significantly more likely to co-title, conditional on purchasing a CRO and are less responsive to both types of vouchers.

To investigate whether there is heterogeneity in response for households who, at baseline, said they would co-title, we repeat the exercise a final time in columns (8)-(10). We find that hypothetical co-titling predicts actual co-titling with certainty (the predicted probability actually falls above one, a byproduct of the linear specification). Also evident is that the effect of the conditional vouchers on co-titling is channeling primarily through households which had not planned to co-title at baseline. We find no heterogenous effects in take-up.

In sum, we find that even small price incentives lead to nearly uniform co-titling, with no reduction in demand for titles.

Moreover, the effect of conditional vouchers on co-titling is at least as strong, and perhaps stronger, for households where women have low bargaining power at baseline. This suggests that insofar as legal co-titling changes bargaining dynamics - a question we return to in the conclusion - price incentives can be effective in inducing these outcomes even in households where bargaining is relatively unequal to begin.

\section{Conclusion}

In this paper, we have presented results from a land titling experiment in Dar es Salaam, Tanzania, where we used targeted subsides to induce random variation in the price that land-owning households faced when purchasing a land title. In addition to these general price discounts, we have reported impacts on overall demand for titling and female cotitling from conditional vouchers that required households to include a woman on the land title application in order to apply the full discount.

We find that conditional subsidies have the same positive impact on demand that general subsidies do. Taken together, willingness to pay for land titles is, on average, 





between $\$ 40$ and $\$ 50$. Combined with the result that co-titling rates under general price subsidies are high, discounting the price of CROs appears to increase the number of female land owners purely by expanding coverage along the extensive margin.

Furthermore, conditional on purchasing a $\mathrm{CRO}$, households which were allocated a conditional voucher were much more likely to include a woman on their title application. The improvements along the intensive margin under conditionality do not compete with those seen along the extensive margin, resulting in drastically better coverage. These results indicate that small price incentives are an effective means of encouraging de jure empowerment of women in the implementation of land titling schemes.

However, it remains to be seen whether or not these strictly legal improvements in women's land ownership will result in actual de facto improvements in the lives of urban landowners, in particular for the lives of women. There are two reasons to be cautious in interpreting these results. First, our results are surprising given the potentially large shifts in bargaining power co-titling implies legally, and the low status quo rates of coownership. If households perceive these legal instruments to be binding on bargaining outcomes in the household, then one might expect those with conditional vouchers to require higher subsidies to compensate those who lose out in this process. This is the "price of empowerment", the amount that would be needed to be transferred to households to offset the decline in demand caused by conditionality. But households in our study treat these vouchers indistinguishably, implying that the price of empowerment is effectively zero. In the context of this intervention, small price incentives are sufficient to overcome any resistance to co-titling. This is encouraging from a simple policy perspective, as it seems particularly easy to nudge women onto land titles, but raises longer-term questions about whether households may be right to behave as if de jure improvements in women's land ownership will not translate into real changes in women's household bargaining power.

And second, in the case of Dar es Salaam, changes in the government's policy toward these new titles that occurred after participants had paid the required fees mean that the road to formal titles remains an arduous one for the landholders in our study area.

Taken together, these results present mixed news for policymakers interested in the legal empowerment of the poor, and of women in particular. On the one hand, small changes in price structure appear to be an affective tool to induce women's access to formal titles, on both the extensive and intensive margins. However, households' demand for such legal protections is only part of the process, and there may remain important challenges in both the delivery and enforcement of these rights by the state that ultimately determine their social impact. Having provided some evidence that price incentives can induce takeup and co-titling, we hope that future research will shed further light on the delivery and enforcement of these legal rights. 


\section{References}

Acemoglu, D. and A. Robinson (2001). The colonial origins of comparative development: An empirical investigation. The American Economic Review 91(5), 13691401 .

Alden Wily, L. (2003). Community-based land tenure management. questions and answers about Tanzania's new Village Land Act, 1999.

Ali, D. A., K. Deininger, and M. Goldstein (2011, August). Environmental and gender impacts of land tenure regularization in Africa : Pilot evidence from Rwanda. (5765). The World Bank, Policy Research Working Paper Series.

Allendorf, K. (2007). Do women's land rights promote empowerment and child health in Nepal? World Development 35(11), 1975-1988.

Baird, S., C. McIntosh, and B. Özler (2011). Cash or condition? evidence from a cash transfer experiment. The Quarterly Journal of Economics, qjr032.

Besley, T. and M. Ghatak (2010, January). Property Rights and Economic Development, Volume 5 of Handbook of Development Economics, Chapter 0, pp. 4525-4595. Elsevier.

Deere, C. and M. León (2001). Who owns the land? Gender and land-titling programmes in Latin America. Journal of Agrarian Change 1(3), 440-467.

Deininger, K., D. A. Ali, S. Holden, and J. Zevenbergen (2008, October). Rural land certification in ethiopia: Process, initial impact, and implications for other african countries. World Development 36(10), 1786-1812.

Di Tella, R., S. Galiani, and E. Schargrodsky (2007, February). The formation of beliefs: Evidence from the allocation of land titles to squatters. Quarterly Journal of Economics 122(1), 209-241.

Doss, C. (2005). The effects of intrahousehold property ownership on expenditure patterns in Ghana. Journal of African Economies 15(1), 149-180.

Doss, C., S. Kim, J. Njuki, E. Hillenbrand, and M. Miruka (2014). Womens individual and joint property ownership: Effects on household decisionmaking. IFPRI Discussion Paper 01347, International Food Policy Research Institute.

Doss, C., C. Kovarik, A. Peterman, A. Quisumbing, and M. van de Bold (2013). Gender inequalities in ownership and control of land in Africa: myths versus reality. IFPRI Discussion Paper 01308, International Food Policy Research Institute.

Field, E. (2003). Fertility responses to urban land titling programs: the roles of ownership security and the distribution of household assets. Working paper, Harvard University. 
Galiani, S. and E. Schargrodsky (2010). Property rights for the poor: effects of land titling. Journal of Public Economics 94(9), 700-729.

Goldstein, M. and C. Udry (2008, December). The profits of power: Land rights and agricultural investment in ghana. Journal of Political Economy 116(6), 981-1022.

Heckman, J. (1979). Sample selection bias as a specification error. Econometrica, 153161.

Lucas, R. E. (1976). Econometric policy evaluation: A critique. In Carnegie-Rochester conference series on public policy, Volume 1, pp. 19-46. Elsevier.

Menon, N., Y. van der Meulen Rodgers, and H. Nguyen (2014). Womens land rights and childrens human capital in vietnam. World Development 54, 18-31.

Newman, C., F. Tarp, and K. van den Broeck (2015). Property rights and productivity: The case of joint land titling in vietnam. Land Economics 91(1), 91-105.

North, D. C. and B. R. Weingast (1989). Constitutions and commitment: the evolution of institutions governing public choice in seventeenth-century england. The Journal of Economic History 49(04), 803-832.

Payne, G., A. Durand-Lasserve, and C. Rakodi (2007). Social and economic impacts of land titling programmes in urban and peri-urban areas: a review of the literature. In World Bank Urban Research Symposium, Volume 14, pp. 16.

Sundet, G. (2005). The 1999 Land Act and Village Land Act: a technical analysis of the practical implications of the Acts.

Sundet, G. (2006). The formalisation process in Tanzania: Is it empowering the poor? Prepared for the Norwegian Embassy in Tanzania.

USAID (2011). Tanzania - property rights and resource governance profile. USAID Land Tenure and Property Rights Portal, available online at http://bit.ly/1muRJPb, last accessed April 22, 2014.

Wang, S. (2011). Property rights and intra-household bargaining. Working paper, University of Pennsylvania.

Wiig, H. (2013). Joint titling in rural peru: Impact on womens participation in household decision-making. World Development 52, 104-119.

Wooldridge, J. (2010). Econometric Analysis of Cross Section and Panel Data. MIT Press.

World Bank (2013). Project paper on a proposed additional credit in the amount of sdr 39.2 million and restructuring to the united republic of tanzania for the private sector competitiveness project. World Bank, available online at http://bit.ly/1lBNpAC, last accessed April 22, 2014. 


\section{A Selection into the applicant group}

Several regressions in this paper rely on CRO application data which is only observable for a subset of CRO-purchasing households who have submitted an application. Consider two equations, the co-titling specification from Subsection 4.2 and a selection equation, where $A_{i}$ is a binary variable equal to one if the household has submitted an application (conditional on purchasing a CRO):

$$
\begin{gathered}
\text { cotitle }_{i}=\gamma_{0}+\gamma_{G} v_{G i}+\gamma_{C} v_{C i}+\gamma_{x} \mathbf{x}+\varepsilon_{i} \\
A_{i}=\gamma+\mathbf{z} \beta_{z}+v_{i}
\end{gathered}
$$

The vector $\mathbf{z}$ comprises observable household characteristics which affect the probability a household submits an application and ordinarily contains all the covariates included in (5). If the error terms of these two equations are uncorrelated, then the determinants of selection are random (conditional on the covariates in (5)). However, if the unobserved determinants of selection are correlated with the unobserved determinants of co-titling, $\operatorname{cov}\left(\varepsilon_{i}, v_{i}\right) \neq 0$, then estimates of $\gamma_{G}$ and $\gamma_{C}$ will be subject to sample selectivity bias. For example, if male-dominated households are less likely to turn in an application, conditional on purchase, and male-dominated households are less likely to co-title, then coefficient estimates in the co-titling equation are likely to be biased.

To account for this bias, we use a standard Heckman selection model, in which we first estimate equation (6) using a probit, then use the predicted values to construct the estimated inverse mills ratio $\frac{\phi\left(\mathbf{z} \widehat{\beta}_{z}\right)}{\Phi\left(\mathbf{z} \widehat{\beta}_{z}\right)}$. If equation (5) is subject to sample selection bias, inclusion of the IMR should correct for it (Heckman 1979). However, in practice, if $\mathbf{z}$ only comprises observable characteristics already included equation (5), then the inverse mills ratio will be strongly collinear with the pre-existing covariates in the outcome equation. For robust identification, we require an observable characteristic which can be included in the selection equation, but reasonably be excluded from the outcome equation. In this case, our 'instrument' of choice is a dummy equal to one if the household resides on the owned parcel. The NGO tasked with managing the repayment programme found it substantially more difficult to reach and follow up with households living away from their parcels, as these households were often located outside of the neighbourhood. Unsurprisingly, households living off of their owned parcel were much less likely to purchase a land title or submit an application. However, conditional on the purchase decision, we argue that the household's residence status can reasonable be excluded from the co-titling equation, as there is no reason to believe that households living on their owned parcel will be more or less likely to include a woman as a landowner.

Table 7 displays the results from four separate specifications. Column (1) displays the results from the main OLS specification, estimating the probability of co-titling on the 
voucher values and a vector of baseline controls. Column (2) uses the Heckman 2-step method of correcting for sample selection bias. ${ }^{20}$ Estimated coefficients from the outcome equation are shown in the top half of the table and those from the first-stage selection estimation are shown in the bottom half (baseline controls are not reported). In the selection specification, the estimated coefficients on the voucher dummies are broadly similar to those in the OLS specification. Indeed, the estimated coefficient of the inverse mills ratio is not statistically significant, indicating that selection is not biasing the OLS results. To test for differences using a different function form, columns (3) and (4) display the results from a probit estimation of the outcome equation and a probit model with Heckman sample selection. ${ }^{21}$ Again, the results are very similar across the two specifications, and a test of independence between the two fails to reject the null of no difference.

\section{B Extra figures,tables and balance tests}

\footnotetext{
${ }^{20}$ The two-stage procedure is more robust to violation of the assumption of bivariate normal error terms.

${ }^{21}$ This procedure is described in Section 17.4.3 in (Wooldridge 2010)
} 
Table 7: Effect of voucher distribution on co-titling, sample selection specification

\begin{tabular}{|c|c|c|c|c|}
\hline & $\begin{array}{l}(1) \\
\text { OLS }\end{array}$ & $\begin{array}{c}(2) \\
\text { Selection }\end{array}$ & $\begin{array}{c}(3) \\
\text { Probit }\end{array}$ & $\begin{array}{c}(4) \\
\text { Selection Probit }\end{array}$ \\
\hline $\begin{array}{l}\text { Main Equation } \\
\text { General voucher ( } \% \text { of TSh } 100 \mathrm{k})\end{array}$ & $\begin{array}{l}-0.156 \\
(0.122)\end{array}$ & $\begin{array}{l}-0.155 \\
(0.132)\end{array}$ & $\begin{array}{l}-0.553 \\
(0.456)\end{array}$ & $\begin{array}{l}-0.470 \\
(0.458)\end{array}$ \\
\hline Conditional voucher ( $\%$ of TSh $100 \mathrm{k}$ ) & $\begin{array}{c}0.325^{* * *} \\
(0.106)\end{array}$ & $\begin{array}{c}0.382^{* * *} \\
(0.124)\end{array}$ & $\begin{array}{c}1.712^{* * *} \\
(0.563)\end{array}$ & $\begin{array}{c}1.790^{* * *} \\
(0.497)\end{array}$ \\
\hline Baseline controls & Yes & Yes & Yes & Yes \\
\hline $\begin{array}{l}\operatorname{Pr}(\text { Application submitted) } \\
\text { General voucher ( } \% \text { of TSh } 100 \mathrm{k})\end{array}$ & & $\begin{array}{l}0.0144 \\
(0.376)\end{array}$ & & $\begin{array}{c}0.130 \\
(0.369)\end{array}$ \\
\hline Conditional voucher ( $\%$ of TSh $100 \mathrm{k}$ ) & & $\begin{array}{l}-0.243 \\
(0.354)\end{array}$ & & $\begin{array}{l}-0.173 \\
(0.354)\end{array}$ \\
\hline HH lives on parcel & & $\begin{array}{c}0.444^{* *} \\
(0.210)\end{array}$ & & $\begin{array}{c}0.531^{* *} \\
(0.209)\end{array}$ \\
\hline Constant & & $\begin{array}{c}0.657 \\
(0.422)\end{array}$ & & $\begin{array}{c}0.487 \\
(0.420)\end{array}$ \\
\hline Baseline controls & & Yes & & Yes \\
\hline$\lambda$ & & $\begin{array}{c}-.344 \\
(0.333)\end{array}$ & & \\
\hline $\begin{array}{l}\chi^{2} \text { (test of indep) } \\
\text { Prob }>\chi^{2}\end{array}$ & & & & $\begin{array}{c}2.55 \\
0.1105\end{array}$ \\
\hline $\begin{array}{l}R^{2} \\
\text { Obs }\end{array}$ & $\begin{array}{c}0.137 \\
263\end{array}$ & 374 & $\begin{array}{c}0.164 \\
263\end{array}$ & 374 \\
\hline
\end{tabular}

Notes: Dependent variable $=1$ if household includes a woman on CRO application. Column (1) shows results from linear probability model. Column (2) uses Heckman 2-step to account for the selection of submitting an application. All controls are included in the selection equation but not reported. A dummy for whether the household resides on the owner parcel is excluded from the second-stage equation. Column (3) shows the raw coefficients from a probit model. Column (4) shows the results from a selection probit with the same exclusion restriction. Main equation shows results from second stage and $\operatorname{Pr}($ application) shows results from first stage.

Robust standard errors ${ }^{*} p<0.10,{ }^{* *} p<0.05,{ }^{* * *} p<0.01$ 
Figure 3: Example vouchers, general and conditional

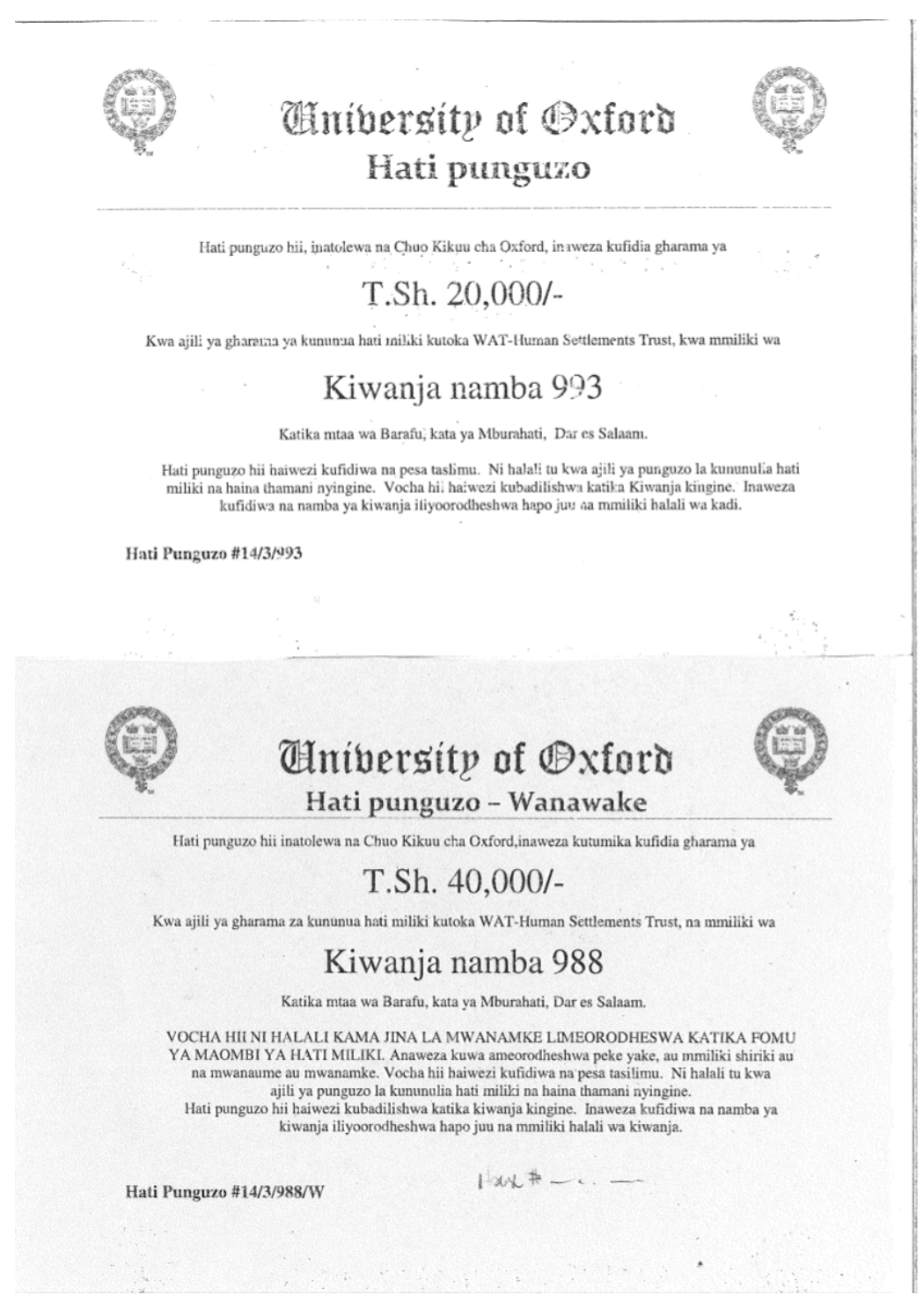

Figure shows two examples of vouchers which households might have received, indicating the conditionality ("wanawake" is Swahili for "woman"), the amount the voucher was worth, as well as the parcel number for which the voucher would apply (kiwanja namba). 


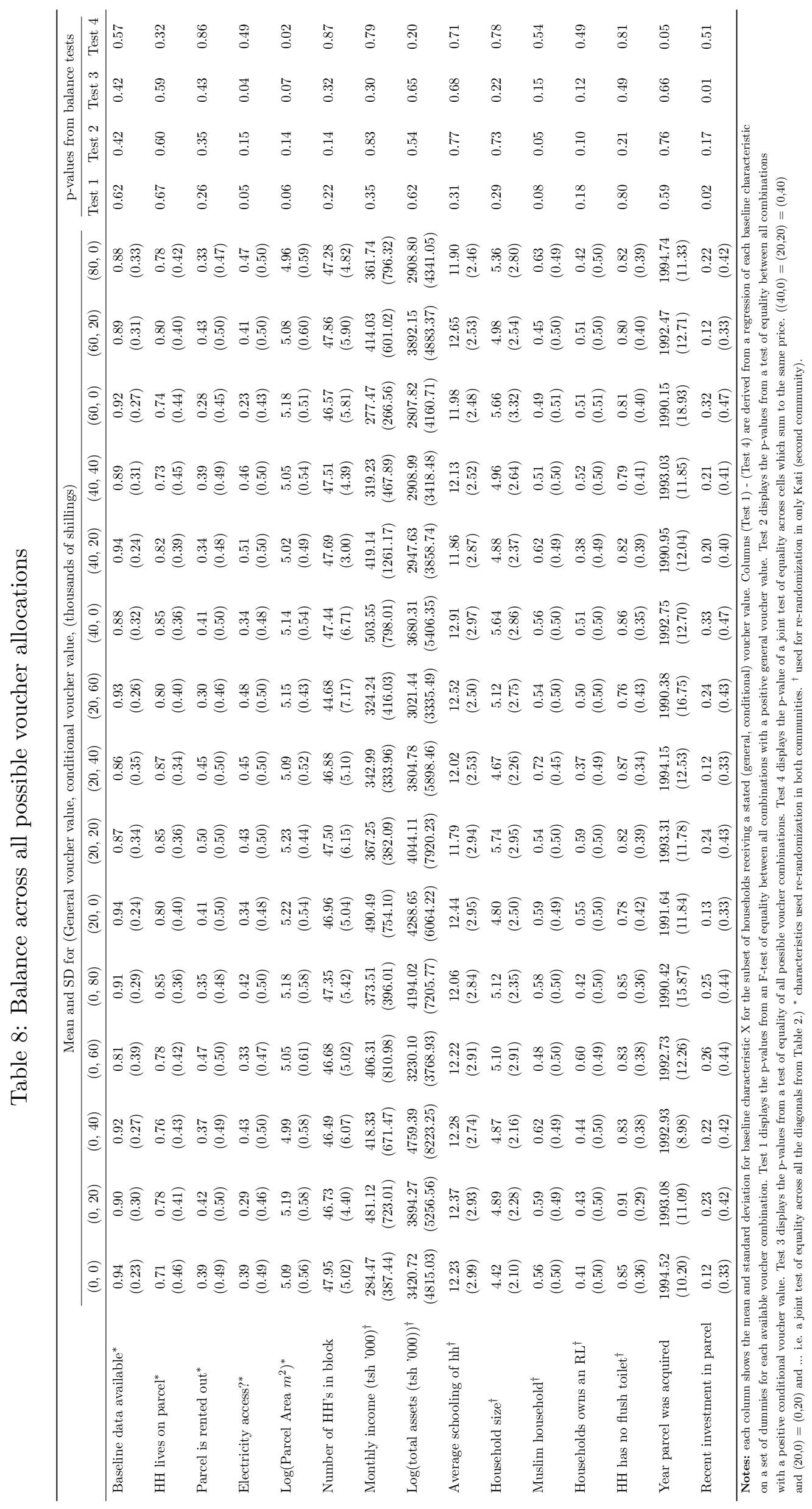


Table 9: Average take-up rate by experimental cell

\begin{tabular}{lcccccc}
\hline & \multicolumn{5}{c}{ Conditional voucher value (thousands of TSh) } \\
\cline { 2 - 7 } & 0 & $20 \mathrm{k}$ & $40 \mathrm{k}$ & $60 \mathrm{k}$ & $80 \mathrm{k}$ & Total \\
\hline General & & & & & & \\
voucher & & & & & & \\
0 & 0.167 & 0.325 & 0.338 & 0.342 & 0.550 & 0.362 \\
& $(0.0551)$ & $(0.0533)$ & $(0.0566)$ & $(0.0571)$ & $(0.0500)$ & $(0.0244)$ \\
$20 \mathrm{k}$ & 0.288 & 0.333 & 0.333 & 0.576 & & 0.378 \\
& $(0.0500)$ & $(0.0661)$ & $(0.0539)$ & $(0.0600)$ & & $(0.0290)$ \\
$40 \mathrm{k}$ & 0.230 & 0.415 & 0.269 & & & 0.306 \\
& $(0.0573)$ & $(0.0602)$ & $(0.0570)$ & & & $0.0346)$ \\
$60 \mathrm{k}$ & 0.383 & 0.490 & & & & 0.439 \\
& $(0.0653)$ & $(0.0680)$ & & & & $0.0486)$ \\
$80 \mathrm{k}$ & 0.375 & & & & & 0.375 \\
& $(0.0528)$ & & & & & \\
Total & 0.285 & 0.383 & 0.314 & 0.453 & 0.550 & 0.364 \\
& $(0.0250)$ & $(0.0306)$ & $(0.0321)$ & $(0.0424)$ & $(0.0500)$ & $(0.0150)$ \\
\hline
\end{tabular}

Note: Each cell shows the unconditional proportion of households who purchased a title, with standard errors in parentheses. Note that the final row presents, e.g. in the first column, the average take-up for all households who received zero conditional voucher, without controlling for their general voucher discount. See Table 2 for observation counts per cell.

Table 10: Average co-titling rate by experimental cell, conditional on take-up

\begin{tabular}{lcccccc}
\hline & \multicolumn{5}{c}{ Conditional voucher value (thousands of TSh) } \\
\cline { 2 - 7 } & 0 & $20 \mathrm{k}$ & $40 \mathrm{k}$ & $60 \mathrm{k}$ & $80 \mathrm{k}$ & Total \\
\hline General & & & & & & \\
voucher & & & & & & \\
0 & 0.667 & 0.933 & 0.938 & 1 & 0.947 & 0.362 \\
& $(0.165)$ & $(0.0846)$ & $(0.0730)$ & $(0.0549)$ & $(0.0367)$ & $(0.0244)$ \\
$20 \mathrm{k}$ & 0.700 & 0.846 & 0.933 & 0.885 & & 0.378 \\
& $(0.110)$ & $(0.0909)$ & $(0.0754)$ & $(0.0482)$ & & $(0.0290)$ \\
$40 \mathrm{k}$ & 0.571 & 0.900 & 0.857 & & & 0.306 \\
& $(0.132)$ & $(0.0733)$ & $(0.0781)$ & & & $(0.0346)$ \\
$60 \mathrm{k}$ & 0.400 & 0.846 & & & & 0.439 \\
& $(0.156)$ & $(0.0909)$ & & & & $0.0486)$ \\
$80 \mathrm{k}$ & 0.650 & & & & & 0.375 \\
& $(0.110)$ & & & & & \\
Total & 0.616 & 0.885 & 0.911 & 0.935 & 0.947 & 0.833 \\
& $(0.0573)$ & $(0.0411)$ & $(0.0429)$ & $(0.0368)$ & $(0.0367)$ & $(0.0231)$ \\
\hline
\end{tabular}

Note: Each cell shows the unconditional proportion of households who listed a woman on their titling application as a share of all households in that cell who purchased a title, with standard errors in parentheses. Note that the final row presents, e.g. in the first column, the average co-titling rate for all purchasing households who received zero conditional voucher, without controlling for their general voucher discount. Obervation counts are equivalent to the numbers in Table 2 multiplied by the take-up rates in Table 9. 


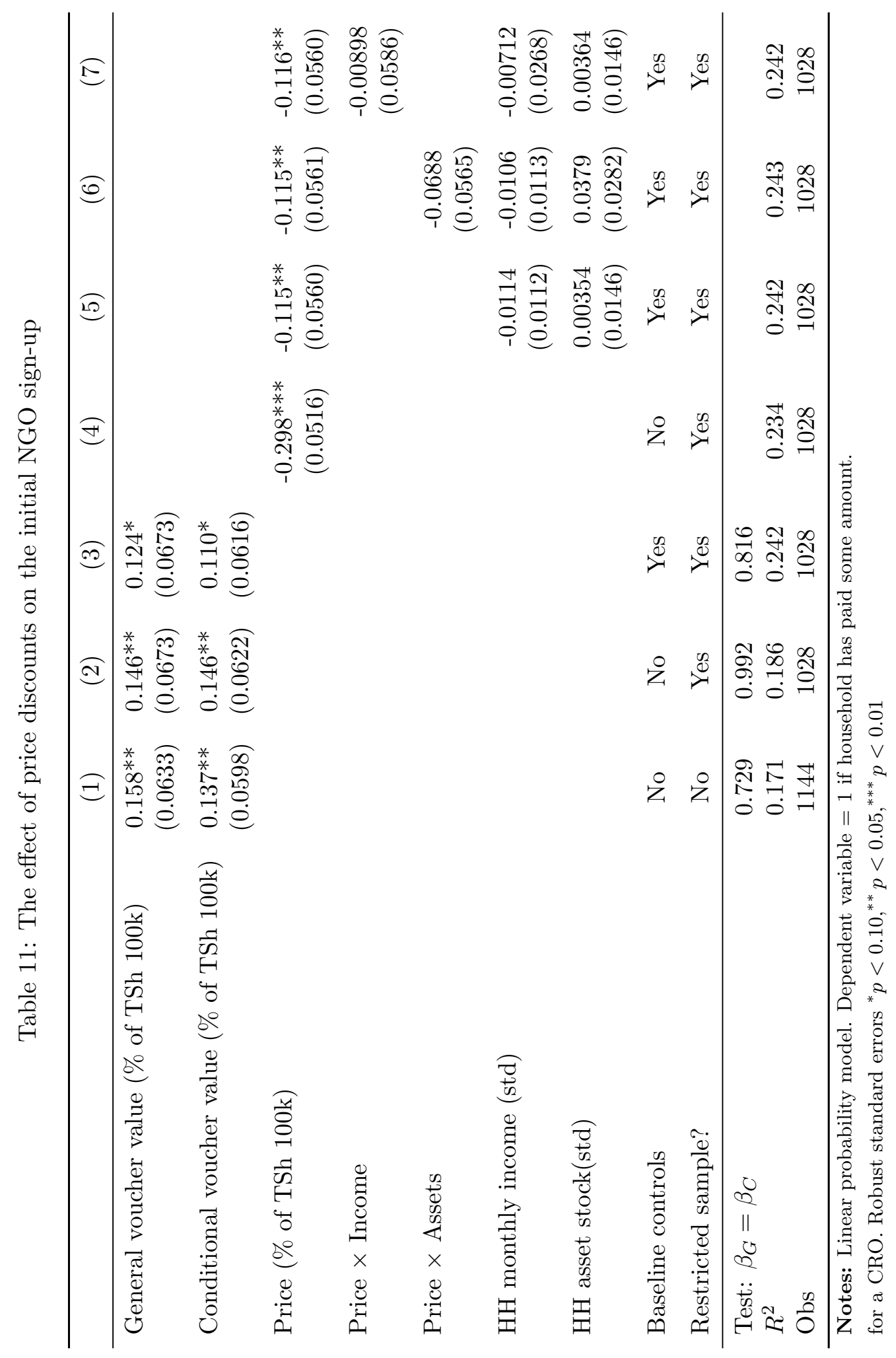

